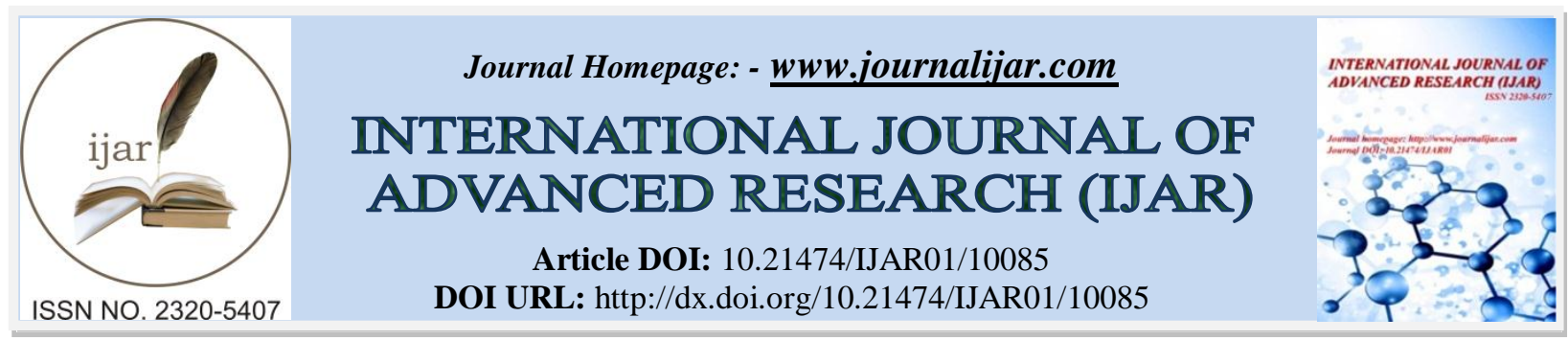

RESEARCH ARTICLE

\title{
DYNAMICS OF DEMOCRATIC SOCIALISM IN INDIA.
}

\author{
Dr. Shahela Yasmeen. \\ Assistant Professor and Head of the department of sociology, Maulana Azad College of Arts, Science and \\ Commerce, Rauza Bagh ,Aurangabad(M.S)431001.
}

\section{Manuscript Info}

Manuscript History

Received: 14 September 2019

Final Accepted: 16 October 2019

Published: November 2019

Key words:-

Democracy Socialism dynamism

Issues.

\section{Abstract}

The ideology of 'Socialism' is the outcome of philosophy of Karl Marx; according to him Socialism, is a society which serves the needs of man. For Marx, socialism meant the social order which permits the return of man to himself, the identity between existence and essence, the overcoming of the separateness and antagonism between subject and object, the humanization of nature; it meant a world in which man is no longer a stranger among strangers, but is in his world, where he is at home. However the term Socialism is often associated with the concept of state ownership of the means of production. However, there are several variants of socialism such as Fabian socialism, utopian socialism and likewise. One such variant is 'Democratic socialism'. The democratic socialism is a way of organizing society that guarantees all people decent and dignified lives. Democratic socialists believe that both the economy and society should run democratically with the aim of fulfilling public needs, and not merely to make profits for a few. Democratic socialism means the blending of socialist and democratic methods together in order to build up an acceptable and viable political and economic structure. To put it in other words, to arrive at socialist goals through democratic means.

Copy Right, IJAR, 2019,. All rights reserved

\section{Introduction:-}

Democratic socialism is a dynamic concept which has changed considerably since independence. However the underlying aim has been modified as per the ideology of ruling parties and their leaders but in doing so the basic aim of fulfilling social needs is vanishing away.

Aim:

The present research aims at describing the changing facets of democratic socialism in India since Independence till present day times and to highlight the emerging issues with the same and provide probable solution to resolve the same.

\section{Objectives:-}

1. To study the ideology of socialism in general and that of democratic socialism in particular.

2. To study the changing facets of democratic socialism in India since independence

3. To highlight the emerging issues in context of changing nature of democratic socialism in India

Corresponding Author:- Dr. Shahela Yasmeen.

Address:- Assistant Professor and Head of the department of sociology, Maulana Azad College of Arts,

Science and Commerce, Rauza Bagh ,Aurangabad(M.S)431001. 
4. To provide probable solutions to overcome the emerging issues

Researchable questions:

1. Q1. What is the ideology of Socialism in general and democratic socialism in particular?

2. Q2. How has the concept of democratic socialism changed since independence?

3. Q3. What are the emerging issues associated with the changing facets democratic socialism?

4. Q4 what are the probable solutions to overcome the emerging issues relating to changing facets of democratic socialism?

\section{Research Methodology:-}

The present research is non empirical in nature. The purpose of research is to give a descriptive analysis of dynamics of democratic socialism in India. The research on the basis of its use will be for impact assessment of changing facets of democratic socialism. The research will be longitudinal as the concept and its implication since independence till present era is taken into consideration. The sources of data collection are secondary and tertiary such as Scholarly articles from journals and magazines, newspaper reports, books and websites.

"Democratic socialism cannot afford to follow dogmas for dogmas' sake but must prove pragmatically through actual accomplishments".

\section{Ebenstein:}

Democratic socialism aims at compromising between extreme individualism-cum-capitalism and extreme communism-cum-totalitarianism by reconciling both. India's parliamentary democracy consists of numerous political parties and regional and provincial groups which is sufficient to disintegrate the interest of the nation. Still attempts are made to reconcile both democracy and socialism for eliminating socio- economic inequalities. Democratic socialism can succeed in India only when class differences are erased and social inequalities are eradicated by the state and its authorities. At the time of adaptation of constitution 'socialist' word was not expressly used but was still working as socialist till emergency era and after $42^{\text {nd }}$ constitutional amendment word socialist was added to the preamble.

Like democracy, Socialism has also lost its true meanings in present day times; it is like a drum which is banged according to the rhythms of those in power as per their whims and fancies.

Democracy In 430 BCE Pericles ${ }^{1}$ described democratic Athens as "the school of Hellas." and its constitution favored many instead of few; and hence called it democracy." 2 The word democracy is derived from Greek word dēmokratiā which is derived from the word demos, "common people" and Kratos, (rule) ${ }^{3}$. The spirit of democracy is embedded in India's cultural ethos since ancient times and was officially adopted as a form of government through the constitutional framework in 1949. India's democracy ensures equal participation of people irrespective of their caste, color, creed, religion, and gender ${ }^{4}$.

Socialism

Collin's Dictionary has defined socialism as "a political ideology which aims for societies in which poverty is eliminated, market forces are not the sole means of the distribution of economic wealth and where the human ideals of cooperation and altruistic behaviour develop". Karl Marx ideology is associated with Socialism; the ideology of socialism was a nineteenth-century development with its roots in the eighteenth century and even earlier. It grew up with industrialization and urbanization; it stressed egalitarian values more than individual freedom. ${ }^{5}$ In a purely

1. Athenian statesman

2. As accessed from 'Encyclopedia Britanica', https://www.britannica.com/topic/democracy/The-theory-ofdemocracy

3. R.A.Dahl, "Democracy", Encyclopedia Britanica, https://www.britannica.com/topic/democracy

4. G. L. BATRA, (2017) "INDiAn DEMOCRACY, A HistoriCAL PERSPECTIVE - THEN AND Now", HTTPS://SPEAKINGTHREADS.COM/2017/01/05/INDIAN-DEMOCRACY-A-HISTORICAL-PERSPECTIVE-THEN-AND-NOW/ OCT 142019 11:11 P.M IST

K. Harrison and T. Boyd, "Socialism in Understanding political ideas and movements", Manchester Open hive open access

Journal

as

accessed

from 
socialist system, all legal production and distribution decisions are made by the government, and individuals completely depend upon state for fulfilling their basic necessities. The government determines the output and pricing levels of these goods and services. Socialists assert that shared ownership of resources and central planning helps in equal distribution of goods and services and lead to equitable society.

Democratic socialism According to Mark A. Peterson ${ }^{6}$, Democratic socialism is "a call for the democraticallyelected to use the public sector to promote greater equality and opportunity." 7 It refers to mixture of socialist and democratic methods together in order to build up an appropriate political and economic structure to meet the needs of the society. It believes that democratic methods are the only means of setting up socialist society. ${ }^{8}$. Democratic socialism is characterized with public ownership of property through a democratically elected government, including most major industries, utilities, and transportation systems, limitation on accumulation of private property, Governmental regulation of the economy, Extensive publicly financed assistance and pension programs, Social costs and the provision of services added to purely financial considerations as the measure of efficiency ${ }^{9}$

It is a system of democratic form of government in which means of production and wealth are owned collectively. It aims to achieve socialist goals of equality but oppose socialist ideologies ${ }^{10}$. Democratic socialists opine that the economy and society should be run democratically in order to meet public needs, instead of benefitting few. Instead of focusing on private profit or an attitude that rewards those who are able to survive, the process of Democratic Socialism is to create a humane vision where everyone has the chance to share their voice while have core supports available to them in a mutually supportive environment ${ }^{11}$.

Democratic socialism and India Social Democratic Theory (also known as democratic socialism) is a political theory referring to the shift from capitalism to socialism. Prior to Independence Gandhiji advocated for socialism by means of common ownership and distribution based upon each according to his ability and each according to his needs; he was against the capitalist principles. For him collective ownership was the only way to abolish the existing inequalities in the society ${ }^{12}$.

According to B.R. Ambedkar 'Social democracy', meant a way of life which recognised liberty, equality and fraternity as the principles of life. These principles of liberty, equality and fraternity were not to be treated as separate items in a trinity ${ }^{13}$. He believed that (socialism) could be achieved through reforms by enlightened elements deploying democratic means. ${ }^{14}$

Pandit Jawaharlal Nehru too believed in the socialism and considered the 'socialist society' as 'good society'. His socialist ideology is reflected in his belief of poverty elimination and development. His approach was based upon

https://www.manchesteropenhive.com/view/9781526137951/9781526137951.00015.xml Oct 14 2019 11:24 P.M IST

${ }^{6}$ Professor of public policy, political science, and law at UCLA,

7 S. Vincenty, "What Is Socialism? And How Is It Different Than Democratic Socialism?", The Oprah Magazine Aug 6, 2019 https://www.oprahmag.com/entertainment/a28588766/what-is-socialism-social-democracy/ Oct 15 2019 11:36 PM IST

8 Nitisha, "Democratic Socialism: Definition, Nature, Methods and Tenets" http://www.politicalsciencenotes.com/socialism/democratic-socialism-definition-nature-methods-and-tenets/817 Oct 152019 11:25 P.M IST

9 L.T. Sargent, "(2008). "The Principles of Democratic Socialism". Contemporary Political Ideologies: A Comparative Analysis” (14th ed.). Wadsworth Publishing. p. 117 as accessed from Wikipedia on Oct 22 2019 12:31 A.M IST

${ }^{10}$ Accessed from http://worldpopulationreview.com/countries/democratic-socialist-countries/Oct 14 2019 11:30 P.M IST

${ }_{11}$ Accessed from https://vittana.org/15-democratic-socialism-pros-and-cons oct 202019 6:27 P.M IST

12 https://www.inc.in/en/congress-sandesh/tribute/gandhian-socialism-and-indian-national-congress OCT 172019 1:38 P.M IST

13 https://www.news18.com/news/tech/b-r-ambedkars-124th-birthday-his-thoughts-on-democracy-untouchabilitygender-equality-981740.html Oct 182019 12:19 A.M IST

14 A. Teltumde, “Ambedkar's socialism: some reflections", http://www.indiaseminar.com/2018/701/701_anand_teltumbde.htm Oct 182019 12:31 A.M IST 
the practical aspect of socialism, rather than theoretical. According to him democracy and civil liberties were basic and inseparable constituents of socialism. ${ }^{15}$

In Second and Third Five Year Plans, Nehru included adopted this socialistic approach. He brought many social reforms, which can be considered as welfare state activities. He also brought labour legislations and equitable distribution of tax and excise policy. ${ }^{16}$

India adopted democratic form of government in its constitution but the word socialist was inserted later by constitutional amendment in 1976 but the nature of constitution was socialist since inception as it included directive principles of state policy based on socialist principles. The idea of socialism as adopted by India is that of a 'democratic socialism' and India adopted mixed economy system with the aim of eradicating issues of social and economic inequalities and introduced the system of reservation for the downtrodden in government jobs, education institutions and legislature. Provisions were inserted in the form of fundamental rights in the constitution and other legal and statutory provisions were made eradicating class differences and other social inequalities. The objectives enshrined in the preamble of the constitution reflect the aim of securing social, political as well as economic justice to all its citizens. ${ }^{17}$ The most prominent feature of the constitution to provide social justice by eradicating social evils of caste discrimination is State affirmative action. Besides these the states had come up with social welfare schemes to help India emerge as a socialist democracy such as: the Right to Education Act-2009, mid-day meals programme1995, Mahatma Gandhi National Rural Employment Guarantee Act-2005, the Food Security Act-2013, and the Sampoorna Grameen Rozgar Yojana-1999. Decentralization of power by establishing Panchayat Raj; also marks a sincere attempt to democratize socially ${ }^{18}$.

\section{Changing facets of democratic socialism in India:}

Jawaharlal Nehru described democratic socialism as one, which will be based on political liberty, equality and tolerance. Under democratic socialism we could maintain individual freedom and initiative with centralized-social control and planning of the economic life of the people. ${ }^{19}$

Over time, "socialism" in Indian politics became synonymous with 'sarvodaya' or the welfare state. ${ }^{20}$ India evolved its own brand of socialism with Indian characteristics. Jawaharlal Nehru, first leader of independent India, openly affirmed to be a socialist ${ }^{21}$. To promote his ideology of socialism he prompted government investment in industrial sector and building infrastructure. Social policies were implemented with the aim of upliftment of poor in education, health and public distribution sectors. ${ }^{22}$. In the 1950s socialist creed was adopted; and the state took custody of steel, mining, machine tools, water, telecommunications, insurance, and electrical plants, among other industries. In 1950 there were 430 commercial banks in India. In 1955 the Imperial Bank in India was nationalised and renamed the State Bank of India. In 1969 all commercial banks holding over Rs.50 crores (just over £200m in modern money) were nationalised. In 1980 all remaining banks were nationalised. Indian Government aimed at eradicating poverty and making India a socialist and welfare state. This was the peak period of India's socialism but still it failed to satisfy the basic needs of an ever expanding population. In 1977-78, more than half of India was living below the

15 Essays, UK. (November 2018). Nehrus Contribution To Socialism In India. Retrieved from https://www.ukessays.com/essays/politics/nehrus-contribution-to-socialism-in-india-politics-essay.php?vref=1 oct 172019 1:50 P.M IST

16 Essays, UK. (November 2018). Nehrus Contribution To Socialism In India. Retrieved from https://www.ukessays.com/essays/politics/nehrus-contribution-to-socialism-in-india-politics-essay.php?vref=1

${ }^{17}$ R.Ram, “Ambedkar \& the Dilemma of Social Democracy",https://www.boloji.com/articles/12416/ambedkar-thedilemma-of-social-democracy Oct 172019 8:2 P.M IST

${ }_{18} 73^{\text {rd }}$ Constitutional Amendment 1993

19 https://www.indianbarassociation.org/socialism-and-its-interpretation-by-the-indian-judiciary/ Oct 202019 6:50P.M IST

${ }^{20}$ E.J Girdner 2013, "Socialism, Sarvodaya and Democracy: The Theoretical Contributions of M.N. Roy, J.P. Narayan and J.B. Kripalani"

21 M. Kilcoyne, "India and the tragedy of socialism", Adam Smith institute July 262018 https://www.adamsmith.org/blog/india-and-the-tragedy-of-socialism Oct 172019 12:56 P.M IST

22 S.L.Rao, “ A new Paradigm”, april 42017 https://www.thehindubusinessline.com/opinion/a-newparadigm/article21948342.ece1\# Oct 172019 8:05 P.M IST 
poverty line ${ }^{23}$. In the year 1991 New Economic Policy of India was launched under the leadership of P. V. Narasimha $\mathrm{Rao}^{24}$; thereby opening the door of Indian economy for global exposure and opened public sectors for the private players; the idea of socialism has been diluted and more thrust is on the private sector. Commercial Banks became independent to determine the rate of interest. Private sector was allowed to set up industries which were previously reserved for the public sector. Many Public Sector Units were sold to private sector. The Government started the process of disinvestment in those Public sector units which had been running into loss. Numbers of industries reserved for public sector were reduced from 17 to $2^{25}$. Reform was very pragmatic, as The Indian economy stabilized and then achieved record growth of 7.5 percent in the three years 1994-97.

India has more "poor" people than any other country on the planet. In 2010, the rich made 12 times more than the poor. ${ }^{26}$ The class differences continue to exist; the world hunger index has ranked India at $102^{\text {nd }}$ out of 117 countries in $2019^{27}$. Its GDP is merely $5 \%$ in $2019 .{ }^{28}$ On the occasion of The $66^{\text {th }}$ Independence Day( $26^{\text {th }}$ January) an advertisement was published in several newspapers in India quoting India's preamble to be, "Sovereign, democratic, republic", and word 'secular' and 'socialist', were missing ." ${ }^{29}$ This gave an indication that the idea of socialism is withering away.

The Government has envisaged a substantive role for Public Private Partnership (PPPs) as a means for connecting private sector investment and operational efficiencies in the provision of public assets and services ${ }^{30}$. The government is moving towards privatizing major public utility services which were government monopoly earlier such as Railways ${ }^{31}$ and Air ports ${ }^{32}$. Education is becoming commodity of rich in the wake of privatization. The gap in Class differences is widening as private bossiness enterprises and industrialist are making it to the list of worlds richest whereas number of people below poverty line are increasing. Social inequalities are increasing on the basis of caste and religion. The affirmative action which aimed to uplift poor has transformed into reservation on the basis of socio-economic backwardness such as Socio-educationally backward class (SEBC) ${ }^{33}$ Economically weaker section $(\mathrm{EWS})^{34}$.

\section{Emerging issues and challenges:}

By the adoption of new economic policy in 1991 a neo-liberal era emerged diluting the spirit of democratic socialism. The market economy which used to be under democratic control was set free for private enterprises. The capitalist started emerging as winning class leaving the working class in the darkness often filled with exploitation in the form of low wages and increased rate of unemployment.

23 L.edwards, "Three Nations That Tried Socialism and Rejected It", as accessed from https://www.nationalreview.com/2019/10/failure-of-socialism-israel-india-united-kingdom-adopted-free-marketpolicies-and-prospered/ oct 202019 8:16 P.M IST

${ }_{25}^{24}$ Former Prime Minister of India

25 H.P.Singh, "New Economic Policy of 1991: Objectives, Features and Impacts", https://www.jagranjosh.com/general-knowledge/new-economic-policy-of-1991-objectives-features-and-impacts1448348633-1 Oct 20, 2019 7:28 P.M IST

${ }^{26} \mathrm{http} / / /$ learningindia.in/indias-by-class/ oct 202019 8:25 P.M IST

${ }^{27}$ Times of India Oct 16, 2019

28 The economic times Aug 16, 2019 as accessed from https://economictimes.indiatimes.com/news/economy/indicators/indias-gdp-growth-slows-to-5-in-april-june-

2019/articleshow/70910682.cms?from=mdr oct 202019 8:43 P.M IST

29 https://www.indiatoday.in/india/north/story/republic-day-ad-faux-pas-secular-socialist-preamble-of-constitutionnarendra-modi-government-237601-2015-01-27 Oct 202019 7:52 P.M IST

${ }^{30}$ India: National Public Private Partnership Policy (draft) available in Pdf onhttps://ppp.worldbank.org/publicprivate-partnership/library/india-national-public-private-partnership-policy

31 The Hindu Business line, Oct 16, 2019 Column by S. Royas accessed from https://www.thehindubusinessline.com/opinion/columns/railway-privatisation-india-must-hasten-

slowly/article29711689.ece\# Oct 222019 10:51 A.M IST

${ }_{32}$ Business Standard E-Paper Nov 9 2018, 2:12 IST column by A. Majumdar

${ }^{33}$ India Today July 12019

${ }^{34}$ 103rd Constitutional Amendment Act, 2019 
Even the sectors where government had control over economy the unpopular, racial ethnic and religious minorities are at stake. Vast number of public sector undertakings is dominated by the political majority. Where the economy is under government control it is using its key resources to support rich industrialist class and turning a blind eye towards poor and downtrodden.

India's constitution aims to provide social justice by eradicating the social evils in the form of caste discrimination, yet the society are not free from prejudice. Series of incidents display the abysmal presence of backward classes especially Dalits, who are often, denied basic rights such as attending regular schools, accessing public water supplies and staging marriage processions ${ }^{35}$. Protection of the interest of minorities is the essence of democracy and important component of socialist character but in fact minorities are over represented in India's prisons and underrepresented in fields of key stakeholders ${ }^{36}$.

In 2017 Budget, the government planned to raise Rs. 72,500 crore through disinvestment of Public Sector Undertakings, thereby making them inaccessible to the poorer section of the society. Budget of the welfare state scrapped the bonded labour rehabilitation scheme. Pre-Matric scholarships have been reduced massively: from 510 crores in the last budget to a mere 50 crores in the era where helping hand is more crucial to reduce illiteracy among poor $^{37}$. In 2019 budget corporate tax with up to Rs 400 crore turnovers slashed to 25 per cent from that of 30 per cent; indirectly heading towards capitalism.

\section{Conclusion:-}

Democratic socialism lies between the ideology of communism and social democracy as the communist ideology aims at centralised economy achieved through revolution and in democratic socialism the idea is to preserve capitalism but according to government regulations and even distribution of resources. However, democratic socialists believe socialism should be achieved, well, democratically.

As observed by Granville Austin, "The constituent assembly in India adopted a democratic constitution which allowed India to become socialist in future".

The government took several measures in the form of nationalization to achieve many of the welfare goals. It prompted growth in the employment generating sectors such as agriculture and allied activities, and small and medium enterprises (SMEs). The economic policy reforms brought several socio- economic changes mostly favourable for capitalist class. The current policies and attitude of Indian government are far from the ideals of democratic socialism.

\section{Suggestions:-}

The goal of government believing in the principles of 'democratic socialism' must always be to remove socioeconomic disparities among the societies, they should strive to provide high-quality education to all and education must be considered as a basic necessity instead of commodity of rich, provisions must be made for social services, and healthcare. Vulnerable minorities must be secured through policy decisions meant for their welfare. Instead of privatization nationalization must be stressed upon.

Democracy is said to e government of the people for the people and by the people and owns socialized economy but if the government itself is acting detrimental to the interest of common man than the common man can turn the government out through democratic means.

\footnotetext{
$\begin{array}{llllll}35 & \text { The } & \text { economic } & \text { times } & \text { Jan } & 19\end{array}$ //economictimes.indiatimes.com/articleshow/67589578.cms?from=mdr\&utm_source=contentofinterest\&utm_mediu m=text\&utm_campaign=cppst Oct 222019 10:37 A.M IST

${ }^{36}$ According to 2015 statistics from the National Crimes Records Bureau,

37 P.G.Ambedkar, N.Misha, Pranjal,Sonali, "Jaitley's Budget -cut for poor loan waivers for the rich", https://www.newsclick.in/jaitleys-budget-cuts-poor-loan-waivers-rich Oct 222019 10:16 A.M IST
} 